Field research article

\title{
Persistent Courage of the Local Women Resistance Toward Undemocratic Policies
}

Titiek Kartika Hendrastiti ${ }^{1}$, Sulistyowati Irianto ${ }^{2}$

${ }^{1}$ Faculty of Social and Political Sciences, University of Bengkulu. Email: titiek_kartika@unib.ac.id

2 Faculty of Law, University of Indonesia. Email: sulis_irianto@yahoo.com

\begin{tabular}{|c|c|}
\hline ARTICLE INFO & ABSTRACT \\
\hline $\begin{array}{l}\text { Keywords: } \\
\text { Ethnography feminist; } \\
\text { women agency; extractive } \\
\text { policies; subaltern identity. } \\
\text { How to cite: } \\
\text { Hendrastiti, T.K., Irianto, } \\
\text { S. (2020). Persistent } \\
\text { Courage of the Local } \\
\text { Women Resistance Toward } \\
\text { Undemocratic Policies. } \\
\text { ETNOSIA: Jurnal } \\
\text { Etnografi Indonesia. 5(2): } \\
\text { 184 - 199 } \\
\text { DOI: } \\
\text { 10.31947/etnosia.v5i2.9863 }\end{array}$ & $\begin{array}{l}\text { This paper focuses on studying local women groups resistance } \\
\text { movement toward the policies regarding a permit for mining activities } \\
\text { in their villages. Although locals have vehemently opposed this } \\
\text { business, the official licenses to continue the activities are remain } \\
\text { being issued by state authority and supported by the local government. } \\
\text { This could be seen as a red flag from the policy that has been } \\
\text { abandoned by local communities' interests. For the past decade, then } \\
\text { being involved in social movements against undemocratic policies has } \\
\text { sign significantly creased. There is no benefit for them from these } \\
\text { policies, and local women also could see that their interests and } \\
\text { knowledge have been ignored. The method used in this study is feminist } \\
\text { ethnography, focusing on two villages as a location of mining } \\
\text { activities. The first is Penago Baru in Seluma, Bengkulu, which has } \\
\text { been exploited for their iron sand, then Praikaroku Jangga in Central } \\
\text { Sumba, East Nusa Tenggara, as the location for gold mining. The } \\
\text { study uses field-talks, in-depth interviews, live-in, thematic group } \\
\text { discussions, and field-notes. The participants lived in a social } \\
\text { movement or acted as indigenous leaders, NGO activists, and demics. } \\
\text { The study shows the distinctive character of these local women } \\
\text { communities, in which they tend to have a subaltern identity. As a } \\
\text { subaltern community, they have never been considered to exist, as } \\
\text { their interests are not included in the policy agenda-setting. Their } \\
\text { resistance is actually a reflection of the state's ignorance of the locals' } \\
\text { rights. The study also notes that local women communities in both } \\
\text { locations are actually reliable agents of local environment knowledge, } \\
\text { with their intimate experiences with surrounding nature. Their } \\
\text { courage to resist these policies is more of an effort to protect the } \\
\text { natural resources and the people, as well as the ecosystem. }\end{array}$ \\
\hline
\end{tabular}

\section{Introduction}

Nexus between state and female citizens is a unique. It contains an inequality collaboration. In general, the concept of citizenship consists of membership, legal status, rights, and participation (Hiariej, 2017). However, in everyday practice, not all citizen enjoys the four elements of the citizenship, especially women. An obvious sign of their 
vulnerabilities is positioning to policies. Lots of journal article report the exclusion of women from decision-making processes, e.g Choudhury \& Mahanta (2018). The inequality exists because in the state discourse tends to be male thought domination (Knuttila, Murray, Kubik, n.d.)

This paper discusses women's resistance to extractive permits given to the corporations, in which women have been excluded from the decision-making cycles. The marginalization of women's interest from the policies, especially on the extraction industry, triggers their disappointment. Dissatisfaction of the local women groups around the mining sites is a background of their resistance.

The last two decades, involvement of the women's community in the anti-mining protest is increasing (Asriani, 2015; Hendrastiti, 2014, 2018; Nugroho, 2015). This trend is, inevitably, triggered by the impact of the mining operations as well. The worst impact of mining operations for the local villagers is especially towards women and children safety. Although, the mining operations give bad impacts on the life of the whole community. Some of the articles note that resistance by local women arose because there were changes in severe environmental conditions and deteriorating very quickly. it has been proven that the extraction process destroys agricultural land, pollutes water sources, triggers drought, depletion of marine food sources, and other local fields of life.

The women's resistances occur to address raising issues - specific local women's interests. Voiced issues are many, mostly, they are the problems faced in day-to-day life of the local context. The issues, of course, are not mainstream on the setting agenda of the state policy. They are not priority issues of public/political interest. On the other hand, local women take certain issues which are threatening their lives. Current studies show women can define what they are experiencing; they are able to predict what will happen if they do not take any action. Local women alarm their situation to the state through their attributes, which unfortunately was not detected by the decision makers. Even, along the line of policy-making process, as well as the implementation, stages of policy do not taken account of the marginal issues. In other words, most interests of women, especially local women who are living in mining areas, left behind.

On the other side, many studies on women and natural resources show that women are actually environmental agencies. Women around the mining areas know how to take care of the environment. The knowledge is contrary to the thinking of mining corporations and the state. That is where the conflict point of interest between the state, the corporation, and women take place.

An important study of local women's resistance to mining corporations is done by (Jenkins, 2017). Local women's resistance in rural Ecuador and Peru against mining corporations is daily resistance, not large and transnational movements. their awareness of the "loss" of local resources takes place every day. the great strength of the mining corporation is definitely taking away their living space. Another study that support Jenkins' findings is research from (Triscritti, 2013). Women's rejection of mining corporations is caused by the decline of natural resources, environmental damage, and land grabbing that push the local communities moved out. 
(Taylor \& Bonner, 2017) confirms that state regulations on undemocratic mining trigger clash with local communities. Case studies in the mining areas of Conga Peru and Alumbrera Argentina show that there are similarities in the outlook of the state discourse. Neoliberalism is used as the basis of state policy since the mining corporation boom in 1980. The neoliberalist economic requires political stability, free trade, and privatization; at the same time the demand for democratization is also mounting; so that physical clash is inevitable. In the clash, the local civilian protestors confront to the police forces and the para military.

The connection between women and nature is not just a myth, the friendship of both is a reality that we can see every day. Some studies have documented women's agency in nature conservation. For example,studies (Hunter, P.R, A.M. Macdonald, 2010; Parker, H., Mason, N., Oates, N., Calow, R., Chadza, W., Ludi, 2016); this study explains that in developing and poor Asian and African countries, there is a real significance between hygienic water and family health. The availability of clean water from local water sources is a women's agency area, but the research does not indicate women's involvement in water management. Water management in some countries remain comprising inappropriate policies. Similar to the study, other studies in Africa and Asia show that women as the main water users are very rarely involved in water governance (Elias, 2015; Michael, 1998; Thai \& Guevara, 2019; Watts, 2004).

In Indonesia, there are three series of editorial books on ecofeminism which publish studies on the environment. Some of them studying about women, water, and (Asriani, 2015). Writings on the issue of environmental damages due to water waste have done by (Handayani, 2014; Hunga, 2014). The studies are interesting because those prove that between women and water has a unique connection. Not only between water and humans, but how to manage water is in the hands of women.

Besides the issue of water, there are several studies on the contribution of women in maintaining soil productivity, forest and sustainability (Priminingtyas, 2007; Yuliati, 2014). Studies on women and their agency in managing the medicinal plants are covered in this series. How women overcome the ecological, food and medicinal crop crisis reported clearly and strongly (Nge, S.T.M \& Purnomo, 2014).

In addition, studies on women's and mining issues also began to emerge, for example (Hendrastiti, 2014), (Apriando, 2015), (Asriani, 2015), (Badawi, 2015), (Jenkins, 2017). All studies of women and mining always contain sad stories of physical and social damages to the local inhabitants, where the mineral extraction business takes place.

Generally, a connection between women and the state crosses at the point of encounter called regulation and policy. The finding of the study shows that women agency in policy is a key. The position of women, as the socio-cultural object (non-subject), becomes the main problem in policies; it is problematic in both sectors, substance and presence. Furthermore, on the issue of women on environmental policy is a clear issue of inequality.

In contrast, women's studies conducted by feminists embrace different things. Women are the subject of nature. Women's daily life experiences give them more knowledge 
about how to interact with the environment. Knowledge makes women expertise in the management of land, water, forest, watersheds, medicinal plants, natural dye yarn weaving, and so on. That kind of knowledge is not recognized and not present in the substance of the policy. The article focuses on the gaps.

\section{Method}

\section{Ethnography of Postcolonial Feminist}

The study adopts a post-colonial feminist ethnography method. Epistemologically, ethnography is identical to the production of knowledge (Hendrastiti, 2014). In the compilation of knowledge, there are many emotional attachments, chaos, despair because of damage and loss of living space, social and cultural deterioration, insults, socio-economic crises, internal and external conflicts of the community. So ethnography recognizes a complex situation in the formation of knowledge. Ethnography provides opportunities to create knowledge with non-rational content. The dynamics of relations between researchers and subjects also become important moments in the production of knowledge.

The ethnography research keeps personal dedication to give effort for a change in community structure, to promote a new structure that is friendlier in looking at subaltern women. Postcolonial feminist ethnography perfects the form of social phenomena by revealing women's life events. Postcolonial feminist ethnography deconstructs patriarchal assumptions, where mining policy is the scope of men, masculinity, in which women have no space for recognition of their life. In the study, it is not only the researcher that rises to grasp knowledge, but the change of life of the subjects in the duration and after the research becomes a measurement of study success. This method improves exploitative relations, narrative silence, and the community's identity deteriorates (Hendrastiti, 2014).

The postcolonial feminist ethnographic method helps reveal why women oppose corporations. The results of postcolonial feminist ethnographic studies at the same time reveal why women oppose mining business permit policies. He also corrects the inequality of views. Fieldwork is one of the important methods for finding behavior, and the symbols of patriarchy, social structure and function which are at the root of inequality.

Feminist ethnography reveals the lives of women who are closed, unloading inaudible female voices. At least the experience of adopting postcolonial feminist ethnography has: (1) documented the life and activism of anti-mining women groups; (2) understanding the perspective of local women who have lost their living space; (3) understand women in the context of anti-mining.

It approaches key resource persons who engages in the movement. It also talked to local leaders, traditional leaders, religious leaders, accompanying NGOs activists, and state actors. The analysis is not only based on the narration of cultural experiences of women's lives, but also to peel into power and structure patterns that limits the lives of the subjects. Analysis, especially, sees the economic and political power over other dimensions of local life, including the negligence of women's lives. 


\section{Result and discussion}

\section{- State Permits and Policies}

An Indonesian mineral and coal law (Undang-Undang Minerba No. 4/2004) is a legal instrument that is used as a basis for reviewing mining problems. The laws is also the legal instrument is also used as the basis for the state giving business licenses to corporations. Unfortunately, in the content of the law there is a charge that is contrary to the environmental protection convention. There are many problems with deforestation, and other environmental damage, even though there is mineral and coal law. Some criticism from JATAM - the mining advocacy network, the law provides space for criminalization of citizens who disrupt mining operations (Maimunah, 2017).

The philosophical relationship between women and nature that is often forgotten when making ecological change policies. It remains a charge of violations of women's rights, contrary to the principle of sustainable development, or the Kyoto protocol on climate change. The presence of the State (at all levels) is really necessary to guarantee these basic principles. In some mining cases, there were alliances among the Government (especially at the Regional levels), people's representation, military personnel, corporations, and international banking/institutions.

According to JATAM records, up to 2011 there were 10,235 mining permits in Indonesia and $75 \%$ of them overlap their status. Indeed, many mining operations licenses have been stalled due to the demands of local residents; but that does not mean the Government revokes the permit. One of the overlapping cases is this matter, the permit is still valid but the operation has stopped because of the conflict. The public only knows that mining operations are stopped; as long as the business permit still exists, the corporation still has the right to carry out the operation. Over time the community also understood that their struggle was not enough to stop mining operations in the field. But revocation of permission is the target of their struggles.

Like other policy issues, the resolution of environmental issues in the two research locations did not involve women's interests. In brief, it can be explained that the exclusivity of women from the policy process starts from the low participation of women in decision-making institutions, for example, in the local People's Representative Council. During the research period, 2014-2019, in East Nusa Tenggara province there were only 7 seats for women (12 percent), while for Central Sumba District during the two periods 2014-2019 and 2019-2024 the local House of Representatives, women's representation was absent.

In some cases, these occur not because there are no women who are ready to participate in the contestation in the Legislative General Election, women's social capital is usually also greater (this is as shown in table 2). However, several obstacles, such as financial capital, internal contestation of political parties, and some voters who are oriented towards money politics are still obstacles to the number of seats won by female candidates. 
The case that occurs in Seluma District, Bengkulu, was the same. There were no seats for women representatives in the local People's Representative Council during the period of research; it is clear that women's interests cannot be accommodated for almost all issues.

\section{- Social-Political Tension: State Policy and Women's Interest}

Reading several journal articles and books, found some basis of the gap between mining policy and women issues. The manuscripts explain some crucial notes on the consequences of policy content that negate the voice, perspective, and presence of women. Below, Table 1 elaborates the gap between state and citizens interests, in particular the women's matters. Implicitly, in various regions, it appears that the practice of mineral extraction cannot tandem with the life of local settlers. Most policies are not only unfriendly to women, but they are also worsening women's lives. The intersectional conflicts of interest between the state and women lies in differences in perspective and interest. Some article reviews on interest conflicts between policies and women are described as follows:

Table 1. Contents of mining policies and consequences in Indonesia

\begin{tabular}{|c|c|}
\hline State Mine Policy & Consequence \\
\hline $\begin{array}{l}\text { - Regulation on Land Used left women } \\
\text { behind }\end{array}$ & $\begin{array}{l}\text { - Endangering water sufficiency, forests, } \\
\text { watersheds, karst, human security, rice } \\
\text { fields, small farms, }\end{array}$ \\
\hline $\begin{array}{l}\text { - Mining policy discourse is not growing to } \\
\text { alleviate people's lives }\end{array}$ & - Creating disasters and ecosystem damages \\
\hline $\begin{array}{l}\text { Policy contents imbalanced power } \\
\text { relation }\end{array}$ & - Climate change \\
\hline - Implicitly pro-corporate & - Destruction of local spiritual values \\
\hline - Following an exploitative principle & $\begin{array}{l}\text { - Social capital destruction at the local } \\
\text { communities }\end{array}$ \\
\hline $\begin{array}{l}\text { Ignoring a sustainable ecosystem } \\
\text { perspective }\end{array}$ & - Women as an object \\
\hline $\begin{array}{l}\text { Policies back up to the elite and the } \\
\text { capital owners }\end{array}$ & $\begin{array}{l}\text { - Women get harder work, and heavier } \\
\text { workloads }\end{array}$ \\
\hline $\begin{array}{l}\text { Women's representation does not have a } \\
\text { strategic position in the policy process. } \\
\text { For example: women's political } \\
\text { representation at all levels remains low; } \\
\text { officials in executive decision makers are } \\
\text { relatively low as well }\end{array}$ & $\begin{array}{l}\text { - Endangering health and reproductive } \\
\text { health }\end{array}$ \\
\hline $\begin{array}{l}\text { - The impact of the policy is a thorough } \\
\text { and extraordinary social change }\end{array}$ & - Threatening women's livelihood \\
\hline $\begin{array}{l}\text { - Law enforcement on field offenses is } \\
\text { inadequate }\end{array}$ & - Threatening food sovereign \\
\hline
\end{tabular}

There are records of women's refusal to state permits to mining corporations. The issues that concern the women's movement also vary. This is important information to review the policy of giving business licenses to mining corporations. In this case, it is predicted that women's interests must not be the concern of the state. Below, Table 2 describes some example of women's movements, place of resistances, and the issues being fought for. 
Table 2: Documented women's struggles against state mine policies

\begin{tabular}{|c|c|c|}
\hline Groups of Resistance & Area of Conflict & Issues of Struggle \\
\hline $\begin{array}{l}\text { Women's Resistance of } \\
\text { Kendeng } 1\end{array}$ & $\begin{array}{c}\text { Rembang Regency (Central } \\
\text { Java) }\end{array}$ & $\begin{array}{c}\text { Cement Factory/Kars } \\
\text { Mining }\end{array}$ \\
\hline $\begin{array}{l}\text { Women's Movement from } \\
\text { Tumpang Pitu }{ }^{2}\end{array}$ & Banyuwangi (East Java) & Gold Mining \\
\hline $\begin{array}{l}\text { Women's Groups from } \\
\text { WALHI (Indonesian Forum } \\
\text { for the Environment) }{ }^{3}\end{array}$ & $\begin{array}{l}\text { Bengkulu, Jambi, West } \\
\text { Sumatra, South Kalimantan, } \\
\text { Central Kalimantan, West } \\
\text { Java }\end{array}$ & Coal mining \\
\hline $\begin{array}{l}\text { Molo Communities \& Mama } \\
\text { Aleta Baum }{ }^{4}\end{array}$ & $\begin{array}{c}\text { Mutis Hills, Molo } \\
\text { East Nusa Tenggara } \\
(1996-1980 s)\end{array}$ & Marble Mining \\
\hline $\begin{array}{l}\text { Amungme \& Comoro } \\
\text { Communities - Mama } \\
\text { Yosepha A Lomang }{ }^{5}\end{array}$ & Papua & $\begin{array}{l}\text { Gold Mining } \\
\text { Freeport Co }\end{array}$ \\
\hline $\begin{array}{l}\text { Dayak Siang Murung } \\
\text { Bakumpai - Mama } \\
\text { Satarinah }{ }^{6}\end{array}$ & $\begin{array}{c}\text { Puruk Cahu } \\
\text { Central Kalimantan }\end{array}$ & $\begin{array}{c}\text { Gold Mining } \\
\text { Indo Muro Kencana Co }\end{array}$ \\
\hline $\begin{array}{l}\text { Zohrc Lombonaung - Mama } \\
\text { Surtini Paputangan }{ }^{7}\end{array}$ & $\begin{array}{c}\text { West Coast Buyat } \\
\text { North Sulawesi } \\
\text { (Also in Sumbawa Island, } \\
\text { West Nusa Tenggara, } \\
\text { Kazakhstan, Kyrgystan, } \\
\text { Uzbekistan, Peru, Brazilia, } \\
\text { Myanmar, Nevada) }\end{array}$ & $\begin{array}{l}\text { Gold Mining } \\
\text { NMR }\end{array}$ \\
\hline
\end{tabular}

\footnotetext{
Sources:

1 Rinaldi, A. (2017). Lingkungan perempuan Kendeng: mata air perlawanan tambang semen. Retrieved from http://www.vice.com

${ }^{2}$ Ariefana, P. (2020). Kenapa tambang emas Tumpang Pitu harus ditolak?. Retrieved from http://www.jatim.suara.com ${ }^{3}$ Walhi. (2018). Stop energi kotor batubara, hentikan kriminalisasi pejuang lingkungan hidup, kedaulatan pangan dan energi. Siaran Pers, Uncategorized. Retrieved from http://walhi.or.id

${ }_{4}^{4}$ Tempo. (2019). Penjaga gunung marmer suku Mollo, memimpin perlawanan kaum perempuan terhadap perusahaan tambang, Aleta Kornelia Baun meneruskan perjuangan di dunia politik. Berkampanye dengan membagikan bibit pohon. Retrieved from http://www.majalah.tempo.com

${ }^{5}$ Jerat Papua. (2014). Stop energi kotor batubara, hentikan kriminalisasi pejuang lingkungan hidup, kedaulatan pangan dan energi. Siaran Pers, Uncategorized. Retrieved from http://jeratpapua.org

${ }^{6}$ Ayiep. (2010). Gambaran konflik masyarakat adat Dayak Siang, Murung dan Bekumpai, melawan PT. Indo Muro Kencana. Retrieved from http://www.ayieffathurahman.wordpress.com

${ }^{7}$ Liputan6. (2004). Newmont Pusat mengakui pencemaran teluk Buyat. Retrieved from http://liputan6.com
}

\section{- Social Protest on Mining}

For a comparison, the stories of women dealing with mining corporations, here will be examined the experiences of Latin American women. Latin America has a long history of social protest and popular opposition to corporations and the state. For instance, the social For instance, the movement from Latin America which was tempered throughout the world and studied in many countries was a rubber tapping farmer movement from Brasilia led by Chico Mendes (trans., 1994). Moreover, several journal articles about social movements against mining corporations from Latin America are interesting to review to strengthen the analysis of this study (Jenkins, 2017; Taylor, 2011).

Taylor and Jenkins studies show that the activism and resistance model of the Ecuadorian and Peruvian Andes society against mining corporate oppression is shown in the activities of daily living. Peruvian and Ecuadorian women used to live in social 
conflict; the conflict they face daily is not a large-scale conflict, nor is it a protest against corporate transnational activity, or a spectacular movement. Women are involved in resistance to the difficulties of everyday life, especially in the presence of mining operations in their villages. Women's resistance is actually an effort to achieve survival in each community. Because the documentation of the women's movement is always present in the daily lives of the community, so by various resistance parties, women are referred to as law fighters and terrorism movements.

The latent protest was indeed able to change power relations within the country; the change is also able to provide greater opportunities and space for collective action in rural areas. Cases in San Maros and Condebamba Valley, Peru, are real examples of the strength of everyday community protests. Corporate activities in the excessive use of water, not only draining rivers and clean water sources around the villages, but also poses the danger of mercury waste. It was there that they spoke up and fought for days. At another time, there was a problem with agricultural land, and it also clashed with mining exploitation activities in the village. Again, local women face mining company workers (Jenkins, 2017; Taylor, 2011) .

Latin America is the largest gold mining area in the world. The cases of mine conflicts, particularly the gold mines, have met much of the publication of social science journals. Almost all articles describe the conflict between corporations - local communities, (Triscritti, 2013) is one of them. Studies at the open-pit gold mine site in Ancash, Cajamarca and La Libertad - Peru areas, find out that there are three main causes of conflict. That are, environmental management, weak institutions, and low central government oversight. Corporate bids for sustainable socio-economic development have never occurred. In addition, the study finding also found that the democratic needs of the democratic framework are not working, since the idea of public-private partnership is a myth.

Supporting Triscriti's study, (Taylor \& Bonner, 2017) study in Cajamarca, Peru and Catamarca, Argentina show that a state response to public protests against gold mining is a form of repression and violence. A policy review is not a policy that prioritizes dialogue; the state instead made a policy that confirmed the expansion of the gold corporation and silenced democracy.

\section{- The courage of local women resists state mining policies}

Documentaries concerning women's resistance to the mining policies in Indonesian context is not only having an economic background. The explanation of the theories and practices of extractive industries in the field shows that they have clearly impacted to the environment, socio-cultural and economy aspects of the local people who live in the operating areas. In addition, the mining operation also addresses to the health hazards. Dangerous substances are threatening the life safety of local inhabitants. Hazardous pollutions attack people's environmental area through water, soil, and air. Learning from the everyday experiences, women see that the corporation violates local economic, social and cultural rights. The damage occurs not only by corporate power, but it become stronger because it is supported by most political power at all levels. 
A review of some writings on women's resistance against extraction policies shows that women resist the policies as their exclusion of mining policy making process. The rationality of women's exclusion from the policies can be seen from the study of (Michael, 1998) in Tanzania and (Thai \& Guevara, 2019) in Vietnam. The studies - with a specific issue on water remind us that almost all women's protest against mining corporations concerning on water pollution. A crucial point of the women's movement is related with water pollution. That is why it is necessary to trace the roots of water problem in mining. We are used to see how women surrounding mining areas move to refuse the extractive mining. Michael and Thai studies have succeeded in showing the logic of why women oppose the governance policies. the clue most aspect of women's resistance to mining corporation operations is the issue of water adequacy.

Even though women are the main water users, the relationship between water management and women is not connected. Some of the studies show that there is disconnection between these elements. Simply, a picture of socio-political exclusion of women in water governance can be seen in Figure 1 below

Figure 1: Women, water and power: three inconsistency of the policy phenomena

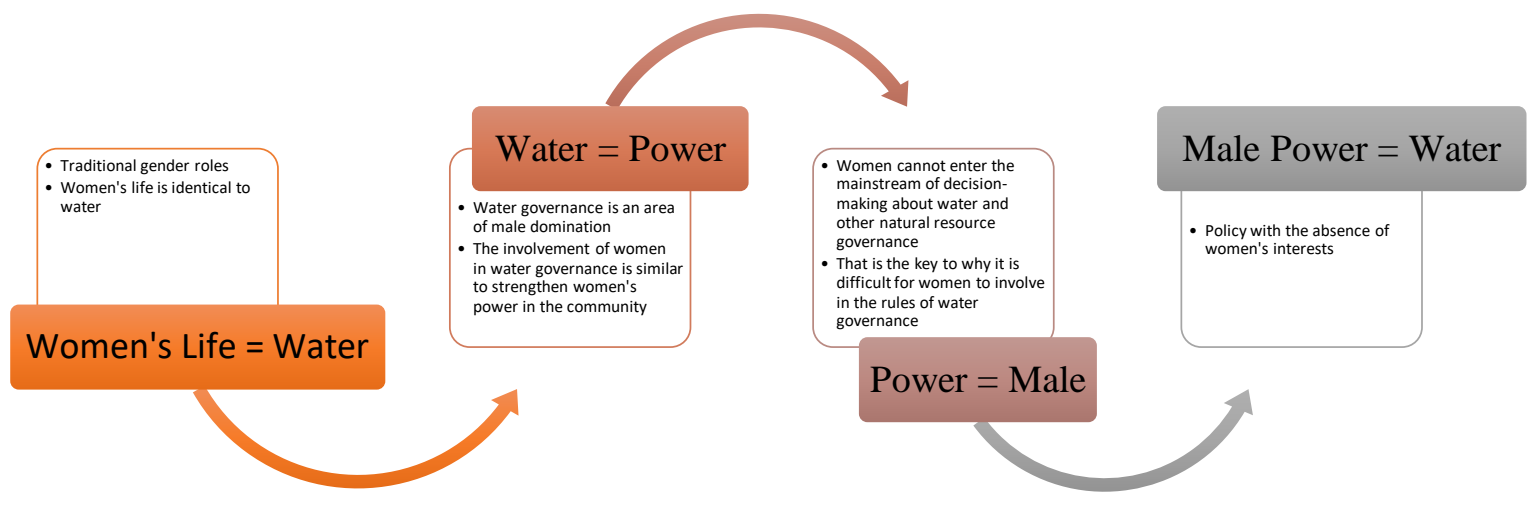

- The strategies of resistance

According to fieldnotes, mostly, resistance to mining corporations begins with individual initiatives. They are the people who experience and deal with daily problems caused by mining activities. Over time, more and more local inhabitants have experienced various hardships in their lives since mining operations began. The difficulties cannot be overcome alone. The emergence of individual awareness encourages locals to organize resistance. Mostly, the steps are similar, but every resistance is unique.

On women's protest, the resistance is related to daily productive and reproductive roles. Symbols of the action reflect their everyday living space. For example, some of them are carrying kitchen utensils, cooking, or carrying children during rallies. the anti-mining community of Penago Baru village, for example, the mothers waved their blouses on rallies. It turns out that they sent a message about hunger; that the iron sand dune mines in their village caused local people to lose agricultural and plantation land; farmland is damaged; and eventually they are starving (Hendrastiti, 2014). 
There is an emerging trend in Indonesia, where women take positions as negotiators. This has been a new strategy to end conflict and win the contestation over the local people's living space. It is due to the context of many Indonesian communities; women, although traditionally placed in the second position, are recognized to be able to find solutions and maintain peace. The involvement of women in a peace negotiation reflects a crucial shift. By involving women in a negotiation process must be read as a "recognition" of women's existence.

Although a revisit study of the anti-mining women's community in Penago Baru shows that after the mine resistance, and the corporation left the village, women return to the domestic positions. This phenomenon needs to be studied more deeply, because various internal political contestations arose after the corporation left the village. The position of "combatant" women in a new era or social change is important.

Table 2 has mentioned that some mining conflicts show the involvement of women in the front line. Even woman's names become the identity of protests against mining corporations. In these two decades women have been seen at the forefront of the movement. For example, a marble mining conflict in Mutis hills, Molo, it is surely the name and identity of Mama Aleta Baun is mentioned (Asriani, 2015). When we discuss the resistance of local residents around the Freeport gold mine in Papua, the name Mama Yosepha A. Lomang will surely appear (Jeratpapua, 2014). It is not only a new trend of social movement, but there is a change in strategy. Local women want to color the antimining upheaval with peace. At least the brutality of the protest actions was replaced by cultural actions impacting profoundly about the fight.

The message sent to the state and corporation is about cultural death, loss of social institutions of the local community due to mineral extraction activities; and economic slowness and the threat of dependence on the local community for the corporation. With the woman in front, the action does not bleed. Resistance attributes are shifted to domestic attributes, such as symbolic bodies and kitchens to illustrate socio-cultural losses due to mining exploitation. Cultural, social and customary values fade out and then disappear. Such loss of the social capital is faced by the people in the area of the mining. The loss of the local community is not only a physical loss, but also a decline in social capital.

As a comparison, Choudhury et al. (2018) on policy making in Bangladesh shows that women indeed excluded from policy making about natural resources. Gender neutral that they make a guide, it turns out that they have not been able to change the position of women from the periphery both in terms of family, community, culture and policy making. Fortunately, they note about the women's position that is dominated by social networks and cultural capital.

(Apriando, 2015) article describes clashes that occur between karst mining policies and women's interests in Central Java for a long time. The case of protest of Kendeng communities (Rembang and Pati) against cement factory and karst mining is essentially in unjust policy. Policy alternated, but clashes between the state - the mining corporation/cement factory - the Kendeng community went on. The case has been sent 
to the State Administrative Court (PTUN). The lawsuit to the Governor of Central Java has never revoked, the dramatic demonstrations have held, until the lobby directly to the President had been carried out. Still, the result until this script is written is floating. It is clear that the policy forgetting women interests, the state forgets the local women knowledge that full of the wisdom of ecosystems, natural threats, and disasters.

In Mollo, women welcomed the "downturn" in the policy through a celebration called the Nifu Paham Festival. The festival's philosophy is the strength of the women's communities in celebrating the success of taking the living space. The festival is also a widely publicized of women's articulation about their experience and knowledge to nature (Asriani, 2015). Asriani's writings are supported by (Badawi, 2015); Badawi's study of state policy undermines the living conditions of women. Mine policy adds to the risk of greater vulnerability of women. Badawi builds its logic through the intermediate phenomenon, which is the risk of climate change. Mining policy has great potential for environmental imbalances. this means that the policy of forgetting the "needs" and "interests" of women and local vulnerable families.

A review to another article, (Parker, H., Mason, N., Oates, N., Calow, R., Chadza, W., Ludi, 2016), indicates that when a natural degradation, drought, and crop failure occurs in an area, it is certain that women bear the greatest risk. Women are accustomed to face the risks of natural change, without any State policy women take a step forward more quickly. They choose some kind of strategies to stay alive. For example, in the farming community, women are informally involved in water management. Parker's article describes the logic women's engagement for nature.

A women's connection to the environment and biodiversity reflects social relations. The social relationships are hereditary and are learned through observation and practice. Women, who are socially and culturally bound to domestic affairs and responsibilities, close to water, land, plants and forests, are at the core of the life knowledge. Without recognition of that, this is one form of oppression. For women, one of the identities of liberation is recognition of their knowledge. In the postcolonial feminist point of view, the various oppressions that place women around the mining is the entry to resist the state policies.

In addition, the oppressive situation in several levels of life cycle also triggers liberation efforts. Poverty due to mine operations, addresses to women - namely the narrowing of the living space poverty, no recovery, the extinction of the physical, social and cultural environment. Change - formally - depends on men. The public knows the role of women only to support men who work as laborers in mining corporations. The consequence is that women are unpaid workers who support the company (Maimunah, 2017)

\section{- Study Cases: Iron Sand in Penago Baru and Gold Mines in Praikaroku Jangga}

The study of women and iron sand mining in Penago Baru village, Seluma, Bengkulu has conducted since 2011. While the expansion of women and mining study to Praikaroku Jangga Village, Central Sumba District, East Nusa Tenggara, has conducted starting in 2016. The emerging of women's movement in both villages is not well documented, although the anti-mining social movements of the two villages are each 
well-known. One of the main objectives of the study in the two villages was to fill the documentation gap.

The documenting of the women's movement is important, because, first, there is the issue of recognition. Female activism is hidden, considered to be a movement to help the movement of men. They are fighting on behalf of the community, in the name of adat where its content is masculine. Documentation will prove that women have their own struggles. Through the experience of the anti-mining movement - the women managed to expand the public space and voice of their knowledge. The anti-mine protest shows their agenda and positioning.

Documentation on an anti-sand mining protest in Penago Baru Village has been published (Hendrastiti, 2014). Fieldwork identifies a multi-face conflict of iron sand mining. Local women become a part of the whole process of conflict. Their activism was started as a result of community disappointment; then it grew to be a big mass protest. For the local women activist, the mass movement has been a part of her-storical transformation against the iron sand mining corporation.

Women know that their environment changes during mining operation. They lost a living harmony with the swamps, the beaches, and the iron sands. After the beach was extracted, it soon degraded the forest beach green belt; trees started to fall rapidly, and the village threatened to sink. The worst, the mining destroyed social capital, due to a pro-contra position.

To response the social problem, women built a collective identity. They construct for their own movement. Their strategy is different from the references of any other movement, where the researcher could not have guessed the unique narrations. Feminist ethnography helps uncover symbols of the anti-mining struggle for iron sand carried out by the women's community. Meanwhile, the postcolonial feminist approach has sharpened the slices of illustrations of local women protest; it shows how the women's identity has composed in the conflict involving a political acquisition of power and the strength of global corporate economy.

Women's leadership shows up; loyalty to leader is also a strong. The loyalty contains ideology and commitment reflects an emotional tight and transcends non-material interests. The picture of loyalty in fighting can be seen from the spirit of a single mother, named Mak Ompong. She often says; "To fight for justice requires ... a fight spirit till death... it is okay facing death in search of justice". The extreme characters of women are formed between incoming pressure and the existing culture. A collective action is believed as a major power to fight against foreign power disturbing individual and collective properties. The spirit of non-cooperativeness, non-negotiation, and espionage strategy is the identity of the local protesters. The way of the women guards their unity in the rally - they maintain consolidation every day and it was able to form a fighting spirit.

Secondly, it is a gold mining conflict at the Praikaroku Jangga Village, Central Sumba. Just like in the village of Penago Baru, Seluma District, Bengkulu, women from Praikaroku village are protesting a gold mining in their village. In fact, the anti-mining documentation is very popular. Unfortunately, not all of the documents about local 
community protest tells the experience of women. Studies show that women have a major contribution to the range of the protest. Like in other social movements, women are responsible for the public kitchen, child protection and logistics. Although hidden, their support is great and meaningful. This feminist ethnographic study collects small narratives about women's involvement.

An interesting resistance idea is Wai Humba Festival. On an island that full of uniqueness, they perform a yearly festival called WaiHumba. ${ }^{1}$ The study notes that the people of Sumba knit their power against the mining corporation through culture, for example a festival. Wai Humba reflects a cultural festival. Right away, women took a part of the adat festival. The festival shows how Sumba communities preserving the sustainability of culture, kinship solidity, the sustainability of bèlis marital system, and the continuity of ancient megalithic tomb-shaped tradition.

Wai is identical with water; while Humba also means water. It is narrated in the documentation of Wai Humba that, traditionally, in the Marapu religion in which the people of Sumba performed ritual ceremonies at the springs. In Marapu, it calls Kalarat Wai. ${ }^{3}$

Wai Humba Festival is also referred to the festival of Three Mountains (which have become the location of springs on the island of Sumba), namely: Wanggameti, Tana Daru, and Yawilla. Wanggameti, located in East Sumba, whose name means to dispel death. It means that Wanggameti gives water, food, wood and medicinal plants to the community. Tana Daru, located in Central Sumba and West Sumba, also provides water, food, wood and medicines. Similarly, Yawilla, located in Southwest Sumba, ensures the availability of water and living resources for the community.

Each festival has a series of agenda, which essentially strengthens the adat and awareness of conserving natural resources, especially keeping the water. Various activities at the festival, for example: traditional ceremonies/rituals, reflections and custom discussions, exhibitions and horses' attractions, local food exhibitions, organic farmings, traditional arts and games, environmental preservation, water conservation, environmental awards, and some other things.

Women are involved in all activities; they are determined to use the Wai Humba festival to strengthen their socio-cultural position and want to formulate water management from a women's perspective. Wai Humba is a tool to expand a new public space for Sumba women, in order to have a more balanced and sustainable life space.

Awareness of the women regarding mining activities must be related to threat of their body, especially reproductive damages. Impact of mining operations has proven to be troublesome to the lives of women surrounding, such as: skin disease, poisonous drinking water, agricultural damage. Linkages between women, mining corporation

${ }^{1}$ Notes of WaiHumba are in http://www.jatam.org ; http://www.kombinasi.net/festival-wai-humbaparade-komunitas-lokal-tolak-tambang or in other web adresses.

${ }^{3}$ Wai is water, the people of Sumba Island named their district capital with Wai in front, Waingapu for the capital of East Sumba District, Waibakul for the capital of Central Sumba District, Waikabubak for the capital of West Sumba District, Waitabula for the capital of Southwest Sumba District. 
ETNOSIA: Jurnal Etnografi Indonesia 5(2): Persistent Courafe of Local Women Resistance...

and the state are always interwined in patriarchal culture and norms. Figure 2 below describes women's concerns that conflicting to corporation and state interests.

Figure 2: Lessons from Anti-Iron Sand and Gold Mining in Penago and Praikaroku Villages

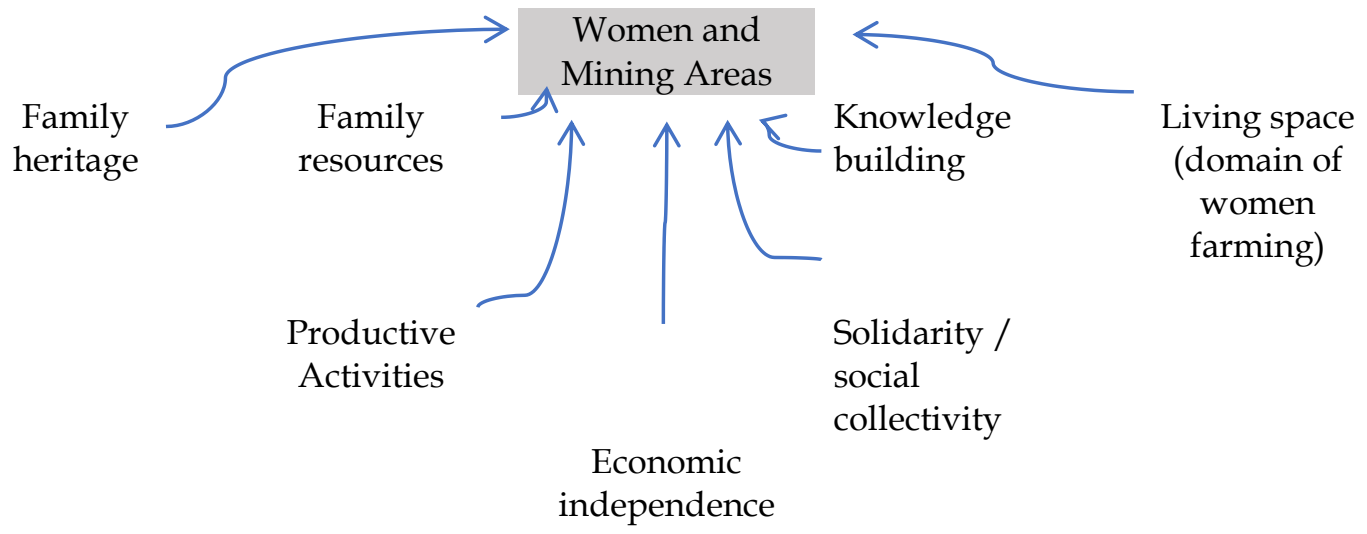

Reviews of the studies show that an encounter conflict between state and women's interests are in the policy. It shows that policy is decided, despite the consequences of them put people live in a more vulnerable situation. Female protests are not considered as an alarm for public policies. It could be possible that women present at the strategic process of decision-making; but yet the interests of women have not been included in policy substances.

\section{Conclusion}

Women are absent in the policy process. Policy makers stay away from women's life in the mining site. Identification of various mine decision-making, at the Center and the Regional Government, shows the existence of ignorance of women's needs. This argument shows that women's interests lag behind the policy.

Women are aware that their knowledge is unacknowledged, unimportant, and outside the context of a power struggle over natural resource assets. At the same time, because of their life experience, women have a strong relationship with nature. Women's knowledge goes beyond the description of the ecosystem. Their daily duties as an environmental care, the guardian of social welfare and food security, make them critical of various forms of natural threat.

Women are involved in the fight against mining policy due to the two considerations; first, their environment is disturbed and damaged. They may lose their future. Secondly, they start to fight because of the new awareness of their status as citizens who are able to voice their interests in the public sphere. They feel that their resistance became stronger; previously their protest was not heard. It is true that women's protests do not change mining policy significantly. But the spirit to fight never dies; they quite understand that one by one the policies are reviewed, and some are revoked their permits. 


\section{Conflicts of interest}

Author declares no conflict of interest.

\section{References}

Apriando, T. (2015). Perempuan Rembang merawat mata air Kendeng: Kajian dampak tambang pada SRHR (Sexual \& Reproductive Health \& Rights). Ekofeminism III: tambang, perubahan iklim \& memori Rahim. Jalasutra.

Asriani, D. D. (2015). Perempuan Mollo merawat tubuh dan alam: Aleta Baun, Paha $\mathrm{Nifu}$, dan pegunungan Mutis. In D. Candraningrum \& A.I.R. Hunga (Eds.). In Ekofeminism III: tambang, perubahan iklim \& memori Rahim (pp. 125-140). Jalasutra.

Badawi, A. (2015). Gap SRHR (Sexual \& Reproductive Health \& Rights) dalam kebijakan perubahan iklim: studi kasus kabupaten Jepara \& Banyumas. In D. Candraningrum \& A.I.R. Hunga (Eds.). Journal of Environment and Earth Science, 3(5). www.iiste.org

Choudhury, R. \& C.M. (2018). Scope and Challenges of Sustainable Drinking Water Management in Assam. In book: Urban Ecology, Water Quality and Climate Change. DOI: 10.1007/978-3-319-74494-0_30

Elias, F. (2015). Women's roles in integrated water resource management: a case study of the Mutale water user association. https://www.researchgate.net/publication/281026879

Handayani, W. \& A. I. K. (2014). Narasi air dan perempuan dalam teknologi daur ulang limbah batik di Masaran Sragen. In D. Candraningrum (Ed.). Ekofeminism II: Narasi iman, mitos, air dan tanah (pp. 251-268). Jalasutra.

Hendrastiti, T. K. (2014). Perempuan Lokal vs Tambang Pasir Besi Global. Yayasan Pustaka Obor Indonesia.

Hendrastiti, T. K. (2018). Ragam identitas perempuan ragam identitas perempuan bukan bayang-bayang: menguatkan konstruksi nasionalisme. Yayasan Pustaka Obor Indonesia.

Hiariej, E. \& K. S. (2017). Politics of Citizenship. Yayasan Pustaka Obor Indonesia in cooperation with PolGov Fisipol UMG and University of Oslo.

Hunga, A. I. R. (2014). Ancaman kerusakan ekologis produksi batik rumahan: narasi perlindungan ruang domestik. In D. Candraningrum (Ed.). Ekofeminism II: Narasi iman, mitos, air dan tanah (pp. 187-212). Jalasutra.

Hunter, P.R, A.M. Macdonald, R. C. C. (2010). Water Supply and Health. PLoS Med. Water Supply and Health. PLoS Med, 7(10). https://doi.org/https:/ /doi:10.1371/journal.pmed.1000361

Jenkins, K. (2017). Women anti-mining activists' narratives of everyday resistance in the Andes: staying put and carrying on in Peru and Ecuador. Gender, Place and Culture, 24(10), https://doi.org/https:/ / doi.org/10.1080/0966369X.2017.1387102

1441-1459.

Jerat Papua. (2014). Stop energi kotor batubara, hentikan kriminalisasi pejuang lingkungan hidup, kedaulatan pangan dan energi. Siaran Pers, Uncategorized. Retrieved from http://jeratpapua.org

Knuttila, Murray, Kubik, W. (n.d.). State Theories: Classical, Global and Feminist Perspectives. Amazon.com. Retrieved August 27, 2020, from https://www.amazon.com/State-Theories-Classical-Feminist-

Perspectives/dp/1856490270

Maimunah, S. (2017). (2017). Kendeng, Perempuan E Pembangunan Yang Memiskinkan. Berjuang menyelamatkan hutan: sebuah kata hati. Yayasan Pustaka Obor Indonesia. 
ETNOSIA: Jurnal Etnografi Indonesia 5(2): Persistent Courafe of Local Women Resistance...

https://indoprogress.com/2017/05/kendeng-perempuan-pembangunan-yangmemiskinkan/

Michael, B. . (1998). The role of women in water resources management: the Tanzania case. International Journal of Water Resources Development, 14(4), 499-504. https://agris.fao.org/agris-search/search.do?recordID=GB1997057744

Nge, S.T.M \& Purnomo, A. W. (2014). Pengetahuan perempuan atas tanaman obat: krisis kesehatan ddan ekologi. In Ekofeminism II: Narasi iman, mitos, air dan tanah (pp. 169186). Jalasutra.

Nugroho, A. C. (2015). Bertani di atas pasir pesisir pantai selatan Yogyakarta: studi kasus perempuan melawan tambang pasir besi. In Ekofeminism III: tambang, perubahan iklim E memori Rahim (pp. 103-124). Jalasutra.

Parker, H., Mason, N., Oates, N., Calow, R., Chadza, W., Ludi, E. (2016). Gender, agriculture, and water insecurity. https://www.odi.org

Priminingtyas, D. N. (2007). Analisis Sosial Ekonomi Peranan Perempuan Pedesaan Di Dalam Keluarga Dan Masyarakat. In Buana Sains (Vol. 7, Issue 2). https:/ / doi.org/10.33366/BS.V7I2.198

Taylor, A., \& Bonner, M. D. (2017). Policing economic growth: Mining, protest, and state discourse in Peru and Argentina. Latin American Research Review, 52(1), 3-17. https://doi.org/10.25222/larr.63

Taylor, L. (2011). Environmentalism and Social Protest: The Contemporary Anti-mining Mobilization in the Province of San Marcos and the Condebamba Valley, Peru. Journal of Agrarian Change, 11(3), 420-439. https://doi.org/10.1111/j.14710366.2011.00313.x

Thai, N. Van, \& Guevara, J. R. (2019). Women and Water Management: A Policy Assessment-A Case Study in An Giang Province, Mekong Delta, Vietnam. AsiaPacific Journal of Rural Development, 29(1), 77-97. https://doi.org/10.1177/1018529119860949

Triscritti, F. (2013). Mining, development and corporate-community conflicts in Peru. Community Development Journal, 48(3), 437-450. https://doi.org/10.1093/cdj/bst024

Watts, S. (2004). Women, water management, and health. Emerging Infectious Diseases, 10(11), 2025-2026. https:/ / doi.org/10.3201/eid1011.040237

Yuliati, Y. (2014). Pengetahuan Perempuan Tengger atas Tanah, Air, dan Hutan. In Ekofeminisme II: Narasi Iman, Mitos, Air, \& Tanah. (p. -). Jalasutra. 